\title{
What Motivates Politicians to Use Strategic Plans as a Decision-Making Tool? Insights from the Theory of Planned Behaviour.
}

\author{
Sebastian Desmidt", Kenn Meyfroodt* \\ *Faculty of Economics and Business Administration, Department Marketing, Innovation \\ and Organization, Ghent University, Ghent, Belgium.
}

Corresponding author: Sebastian Desmidt, e-mail: sebastian.desmidt@ugent.be, Tel: +32(0)92432958, ORCID 0000-0002-5769-4440.

Kenn Meyfroodt, e-mail: kenn.meyfroodt@ugent.be, Tel: +32(0)92432957, ORCID 0000-0002-0587-1732.

Sebastian Desmidt is associate professor of strategic management in the Faculty of Economics and Business Administration, Ghent University, Belgium. His research focuses on the effectiveness of strategic management instruments and strategic planning processes, the determinants of strategic consensus, and the motivational power of mission valence in public and non-profit organizations.

Kenn Meyfroodt is doctoral researcher in strategic management in the Faculty of Economics and Business Administration, Ghent University, Belgium. His research focuses on strategic planning processes, decision making, and the role of strategic consensus in public strategic decisionmaking teams.

A first version of this article was presented at the International Research Society for Public Management Conference at the Corvinus University of Budapest, Hungary, April 19 - 21, 2017. 


\title{
What Motivates Politicians to Use Strategic Plans as a Decision-Making Tool? Insights from the Theory of Planned Behaviour.
}

\begin{abstract}
Although in many public organizations politicians sitting in governing boards are responsible for ratifying the organization's strategic plan and monitoring its implementation, empirical insights on the determinants of politicians' strategic plan use are lacking. Therefore, we build on the theory of planned behaviour to analyse (1) how politicians' beliefs regarding the usefulness of strategic planning, the pressure to use strategic plans, and their self-efficacy in using strategic plans effectively are formed, and (2) how these beliefs impact intended and actual strategic plan use. Longitudinal data from 249 councillors (153 Flemish local authorities) provides support for the developed psychological-cognitive model.
\end{abstract}

Keywords: strategic plan, politicians, theory of planned behaviour

\section{Introduction}

The performance of public organizations is a joined responsibility of politicians and public managers (Jacobsen 2006; Meier, and O'Toole 2006; Walker, Jung, and Boyne 2013) whereby politicians serving on governing boards are not only responsible for defining the organization's broad strategic directions but also for monitoring strategy implementation (Jacobsen 2006; Walker, Jung, and Boyne 2013). One instrument which has been deemed highly relevant to help politicians fulfil their strategic roles effectively during strategy implementation are strategic plans (Bryson, Crosby, and Bryson 2009; Long and Franklin 2004; Vaara, Sorsa, and Pälli 2010) because strategic plans can function as a reference frame which helps politicians to assess bureaucratic actions and to make sense of unfolding events (Kellermanns et al. 2005).

The question, however, if politicians actually use strategic plans as a governance and decision-making support tool has been rarely addressed. This observation leads to the 
contradiction that although (1) in many public organizations politicians are legally responsible for defining the outlines of the organization's strategic plan, ratifying the plan as well as monitoring plan implementation, and (2) the literature indicates that the beneficial effects of strategic plans are contingent upon the extent to which strategic plans are used by all strategic actors (Elbanna, Andrews, and Pollanen 2016; Wolf, and Floyd 2017), academic knowledge on strategic plan use ${ }^{1}$ by politicians is limited. To shed light on the cited research gap, the study at hand focusses on two research questions: (1) to what extent do politicians serving on governing boards use strategic plans as a governance and decision-making support tool, and (2) what are the motivational mechanisms prompting strategic plan use? To answer these questions a theoretical model was developed, based on Ajzen's (1991) theory of planned behaviour (TPB), which argues that (1) attitudes towards strategic planning, (2) perceived pressure to use strategic plans and (3) perceived behavioural control are related to politicians' intended and actual use of strategic plans. The developed theoretical model is tested by means of cluster-adjusted

\footnotetext{
${ }^{1}$ Within the context of this study, strategic plans are viewed as organizational artefacts which express the intended strategy of a public organization. One of the purposes of these strategic plans is to act as a frame of reference for politicians serving on governing boards during strategy implementation (Spee, and Jarzabkowski 2011; Vaara, Sorsa, and Palli 2010). Specifically, as 'the environment of any organization is too complex to be systematically analysed, predicted, and controlled' (Andrews, Beynon, and Genc 2017, 4), strategic decisions need to be refined and adjusted as unforeseen issues arise during strategy implementation (Mason, and Mitroff 1981; Mintzberg, Raisinghani, and Theoret 1976). Strategic plans are thus not only expected to help board members to monitor strategy implementation but also to assist them in dealing with unfolding events during strategy implementation (Kellermanns et al. 2005) and to ascertain that issues are resolved in a way that is consistent with the intention behind the strategic plan (Amason 1996). Consequently, the concept of "strategic plan use" denotes the extent to which board members consult the organization's strategic plan when they need to make decisions during strategy implementation or monitor organizational performance. Strategic plan use thus entails the extent to which board members use the organization's strategic plan as an information source during decision-making processes. Consultation of the organization's strategic plan, however, does not imply that board members are "bounded" by the strategic plan and that there is no room for adjustments or deviations.
} 
Structural Equation Modelling (SEM) using longitudinal data from 249 council members of 153 Flemish local authorities (Belgium) which are mandated by their regional government to develop a strategic plan.

The study contributes to the literature in at least three ways. First, the study results add to the growth of a nascent body of research using a micro-level perspective to focus on attitudes and behaviour of key actors involved in strategic planning processes (Bryson, Crosby, and Bryson 2009; George 2017; George et al. 2017). By focusing on strategic plan use as dependent variable, the study results provide insights into a mediating planning process variable which can help explain how strategic planning contributes to improved decision-making and, ultimately, organizational performance (Wolf, and Floyd 2017). The study results thus counterbalance that although it is almost unimaginable to 'expect any sort of direct, causal connection between the existence of a strategic plan and performance' (Bryson, Berry, and Yang 2010, 509), empirical insights on the factors which potentially mediate the planning-performance relationship are limited (George et al. 2017; 2018; Poister 2010). Second, the study results contribute to the literature on public strategic planning by focusing on an often-neglected subgroup of strategic actors (Askim 2009; Desmidt, Meyfroodt, and George 2019; Nielsen and Baekgaard 2015), namely politicians serving on the boards of public organizations. Despite the fact that legislators across national contexts have mandated public organizations in a variety of settings to adopt strategic planning processes (Meyfroodt, Desmidt, and Goeminne 2019) and thus 'forced' politicians to use planning tools, evidence from a variety of fields demonstrates that mandating the use of decision tools does not always leads to the adoption of these instruments (Boyne et al. 2005). Hence, more research is needed which analyses the actual utilization of such imposed practices by politicians (Walker, and 
Brewer 2008, Walker, Avellaneda, and Berry 2011). Gaining insights into the extent to which politicians, in practice, use these imposed management tools is especially relevant given that the managerial rationality underlying these instruments (Boyne, Law, and Walker 2004) could be 'such a challenge to the local politicians' traditional behaviour that a certain amount of reluctance and prevarication is to be expected' (Vabo 2000,343).

Third, by analysing the psychosocial variables (Ajzen 1991) impacting strategic plan use the study results not only answer Bryson's $(2010,259)$ call 'for better practiceoriented theory to help guide [...] strategic planning' but also behavioural public administration's plea to focus research efforts, through insights from psychology, on the micro-level of individual behaviour and attitudes (Grimmelikhuijsen et al. 2017). Given that rational planning instruments, like strategic plans, are supposed to foster decision quality by ensuring that decisions are 'taken logically on the basis of comprehensive information, rather than intuitively on the basis of incomplete or inaccurate data' (Boyne 2001, 76), insights into the psychological and institutional factors which might impede or stimulate the use of such strategic artefacts are indispensable (Van Dooren, and Hoffmann 2018) as this knowledge may (1) counterbalance the fact that more work is needed on the role strategic plans can play in fostering strategic planning success (Bryson, Edwards, and Van Slyke 2018), and (2) lead to the development of sound interventions which can help strategic plans to make the transition from paper tigers to actual decision-making support tools.

In what follows, we discuss theory, formulate hypotheses, elaborate on our methods and present the results of our study. The study findings indicate that although politicians are often expected to display a certain amount of reluctance towards the adoption of managerial innovations (Vabo 2000), politicians are, on average, in favour of 
strategic planning and use the strategic plan of their local authority as a frame of reference during decision-making processes. The detected relatively high level of variance in strategic plan use by politicians, however, indicates that mandating the use of a management tool does not always result in the intended behavioural changes in practice. Politicians with lower levels of perceived behavioural control and/or hesitations about the benefits of strategic planning are less likely to use their local authority's strategic plan. The fact that a large proportion of the politicians report that they are doubtful about their capabilities to correctly interpret their local authorities' strategic plan needs to be the subject of further research given that the detected variance in perceived behavioural control could suggest that many (part-time lay) politicians struggle with the increased focus on strategic planning within local authorities which, in turn, could hinder their ability to carry out their democratic responsibility for organizational outcomes (Walker, Jung, and Boyne 2013).

\section{Theory and Hypotheses}

Instigated by the popularity of the New Public Management (NPM) reform movement, the adoption of rational planning practices has become widespread within public organizations (Boyne, and Walker 2010; Bryson 2010; Bryson, Edwards, and Van Slyke 2018; Meyfroodt, Desmidt, and Goeminne 2019). Rational planning promotes the use of strategic planning to define strategic goals and performance measurement to evaluate the implementation of the formulated strategic goals (Boyne 2001; George et al. 2017; Poister, Pasha, and Edwards 2013). Pivotal within this rational approach is often the development of a formal strategic plan. As an exponent of the "new" managerial approach (Liguori, Sicilia, and Steccolini 2009), strategic plans are viewed as a management tool 
which can improve the governance of public organisations (Bryson, Crosby, and Bryson 2009; Long and Franklin 2004; Vaara, Sorsa, and Pälli 2010) because strategic plans not only allow politicians to achieve a 'more efficient control of [...] service production, better monitoring and follow-up of political decisions [and] more systematic evaluation of results' (Kleven et al. 2000, 106) but also facilitate the dialogue between a public organization's politicized governing board and its management (Hansen 2001). Specifically, as a structural representation of the organization's intended strategy (Spee, and Jarzabkowski 2011), a strategic plan is intended to act as a reference frame which allows politicians to assess bureaucratic actions and performance and as such alleviates the information asymmetries, as noted by agency theory (Moynihan, Pandey, and Wright 2012), between politicians and public managers (Grissom 2009; Walker, Boyne, and Brewer 2010; Walker, Jung, and Boyne 2013). Reducing these information asymmetries empowers politicians 'to carry out their democratic responsibility for organizational outcomes and meet the requirements of internal control and external accountability' (Walker, Jung, and Boyne 2013, 835). Second, strategic plans can also contribute to the effectiveness of strategy implementation by stimulating strategic conversations within governing boards as well as between such a body and the public managers responsible for strategy implementation (Spee, and Jarzabkowski 2009). According to stewardship theory (Huse 2005), such activities foster strategic thinking, acting, and learning (Bryson 2010) and help to resolve strategic issues in a way that is consistent with the formulated strategic priorities (Pandey, and Garnett 2006).

In an attempt to harvest the presumed benefits of strategic planning, legislators across national contexts have mandated, using legislation or regulation, public organizations in a variety of settings to adopt strategic planning processes and to develop 
strategic plans (Meyfroodt, Desmidt, and Goeminne 2019). Such mandates can be viewed as an "authority decision" by a higher government (Boyne et al. 2005) intended to coerce new managerial behaviours by imposing the adoption of new practices (Armbruster et al. 2008). Boyne et al. (2005, 419), however, stressed that there is 'evidence from a variety of fields [which] clearly indicates that authority decision policies are not necessarily adopted' and thus argue that research should not focus on the decision to impose a new practice but, instead, on the actual utilization of these practices and the reasons why adoption may vary (Walker, and Brewer 2008, Walker, Avellaneda, and Berry 2011). Analysing the behavioural determinants of strategic plan use by local politicians is consequently a fruitful research avenue because albeit the omnipresence of legal frameworks mandating the use of strategic plans, research indicates that the technicality of strategic planning processes and the underlying managerial rationality (Boyne, Law, and Walker 2004) could be 'such a challenge to the local politicians' traditional behaviour that a certain amount of reluctance and prevarication is to be expected' (Vabo 2000,343).

Building on the assumption that the adoption of strategic planning processes (Berry 1994; Walker, and Brewer 2008, Walker, Avellaneda, and Berry 2011), and the ensuing expected strategic plan use require behavioural adjustments, the study's hypotheses are framed within the TPB. TPB is an expectancy value theory developed as an extension of the theory of reasoned action (Ajzen 1991; Ajzen, and Fishbein 1980; Fishbein, and Ajzen 1975) and is argued to be able to explain any social behaviour (Fishbein, and Ajzen 2011). To date, TPB is viewed as 'the most prominent and one of the most successful approaches to model behaviour from a reasoned action perspective' (Kroll 2015b, 202). The central tenet of TPB is that individuals' intention to perform a given behaviour is a strong indicator of actual behaviour (Ajzen 1991, 185). An 
individual's willingness to perform a given behaviour, in turn, is argued to be a function of three behavioural predictors: an individual's (1) beliefs about the likely consequences of performing the behaviour (i.e., attitude), (2) perceived expectation of others regarding the performance of a behaviour (i.e., subjective or social norm), and (3) perceived ability to perform a behaviour (i.e., behavioural control) (Ajzen 1991, Stanec 2009).

Although TPB has, to our knowledge, not yet been used to assess the motivational mechanisms explaining strategic plan use, there are examples of research indicating that TPB can be used to predict the use of rational planning instruments and management tools by organizational decision makers. Stevens et al. (2005), for example, used TPB to gain insights into the determinants of the use of a code of ethics by financial executives. Oliveira, Jarzabkowski, and Lee (2014) employed TPB to analyse managers' willingness to use strategy tools while Kroll (2015b) used TPB to examine the drivers of performance information use by public managers. Building on these studies, we use TPB to assess the motivational mechanisms prompting the use of strategic plans as a governance and decision-making support tool by local politicians. Specifically, we examine the following questions: (1) How are politicians' beliefs regarding the benefits of strategic plan use related to their intended and actual use of mandated strategic plans?; (2) How are perceived pressures from different social referents to engage in strategic planning related to politicians' intended and actual use of mandated strategic plans, and are some social referents more influential than others?; (3) How is perceived behavioural control related to politicians' intended and actual use of mandated strategic plans and what factors (i.e., experience with strategic planning, training related to strategic planning and received information on the planning process) influence politicians' perceived behavioural control? Figure 1 depicts the study's research model. 
[Insert Figure 1 about here]

\section{Attitude}

Aligned with the subjective expected utility or expectancy value perspective on decisionmaking (Fishbein, and Ajzen 1975), TPB argues that an individual's willingness to perform a specific behaviour is strongly influenced by his or her beliefs about the potential benefits associated with performing that behaviour (Stevens et al. 2005). This perspective resonates with the "instrumental efficiency" concept used in the innovation diffusion literature (Bush 1987). This literature argues that decision-makers' intention to adopt a practice or process is dependent on whether the potential beneficial outcomes associated with adoption outweigh the expected costs (Oliveira, Jarzabkowski, and Lee 2014). In the case of politicians, scholars have argued that the outcome of such a costbenefit analysis will often be unsatisfactory, and thus has a negative impact on politicians' adoption of management tools (Diefenbach 2009, Pollitt, and Bouckaert 2011, Buylen, and Christiaens 2014), because the underlying managerial rationality appears to be at odds with the reality of democratic politics and public decision-making (Hansen 2001). Specifically, "new" managerial approaches, such as rational planning practices, appear to shift power from politicians to public managers whereby 'the primacy of politics gives way to the primacy of management' (Liguori, Sicilia, and Steccolini 2012, 906). These tools propagate a rationale based on "economic efficiency" which is probably not the same as "political efficiency" (Hansen, and Ejersbo 2002; Ter Bogt 2004) which states that politicians are primarily driven by attracting voters, realizing policy preferences and/or gaining political advantages (Buylen, and Christiaens 2014; Hansen, and Ejersbo 2002; Ter Bogt 2004). Hence, the adoption of rational decision-making procedures could be perceived by politicians as a limitation of their autonomy and possibilities to address 
constituency cases (Hansen, and Ejersbo 2002).

Other scholars, however, stress that although politicians and public managers have different rationalities (as suggested by the Dichotomy-Duality-Model [Svara 1985]), empirical evidence now emphasizes their complementarity and interdependency rather than their dichotomy (Korac, Saliterer, and Walker 2017; Svara 1999; 2001). Liguori, Sicilia, and Steccolini (2009), for example, argued that politicians' perceptions about their organizational roles vary amongst a continuum: some consider all "new" managerial approaches as a degradation of the political primacy while other politicians view NPMinspired tools as facilitators of sound governance. Politicians' perceptions of the benefits of the adoption of NPM-related tools are deemed highly relevant as they are expected to impact politicians' use of NPM-related tools (Saliterer, and Korac 2014). Boyne et al. (2004, 347) underlined the importance of these pre-existing beliefs by stating that it is important to note that 'a new planning system does not enter a vacuum but replaces preexisting organizational processes. The responses of different groups to the introduction of planning will [thus] partly depend on whether they prefer the old or the new regime'. Consequently, we argue that politicians' beliefs regarding the benefits associated with adopting strategic planning systems are positively related to their intended and actual strategic plan use.

Hypothesis 1. Attitudes towards strategic planning are positively related to intended strategic plan use which, in turn, impacts actual strategic plan use.

\section{Subjective Norm: A Factor of Organizational and External Pressures}

There are increasing pressures on public organizations to adopt new practices aimed at fostering organizational efficiency, enhancing performance and strengthening legitimacy (Barrutia, and Echebarria 2019; De Vries, Bekkers, and Tummers 2016; Van de Walle 
2018; Verhoest, Verschuere, and Bouckaert 2007; Walker 2008). A central notion of TPB deals with the impact of such external pressure on the behaviour of individuals as TPB states that individual behaviour is influenced by an individual's social context and more specifically by his or her perceptions of social normative pressures to engage in a specific behaviour (i.e., subjective norm) (Ajzen 1991). Aligned with TPB, a growing body of research provides evidence that social norms play a significant role in the dissemination and use of management ideas and instruments within the public sector: e.g., Bryson, Edwards, and Van Slyke (2018) on strategic planning, Kroll (2015a) on the use of performance information, Lee, McGuire, and Kim (2017) on the use of outcome measures, and Teodoro (2014) on how profession norms impact the behaviour of local government executives. Consequently, higher levels of perceived social pressure to adopt a strategic planning process are expected to be positively related to politicians' intention to use strategic plans as a decision-making instrument. Given that high levels of perceived social pressure can act as an extrinsic motivational force which triggers specific behaviour in an attempt to satisfy an external demand, to avoid blame or to attain ego enhancements by demonstrating ability (Demircioglu 2019; Ryan and Deci 2000a; 2000b), we hypothesize that:

Hypothesis 2a. Perceived subjective norm to use strategic plans is positively related to intended strategic plan use which, in turn, positively impacts actual strategic plan use.

Attributing high significance to the impact of an individual's social context prompts the question which social influencers impact the formation of subjective norms and, ultimately, individual behaviour. Based on prior research of Oliveira, Jarzabkowski, and Lee (2014), we focus on the impact of two specific sources: organizational referents 
(i.e., influencers within the organizational network of politicians) and external referents (i.e., influencers outside the politician's organization with whom direct interaction is often limited but by whom the organizational context is influenced). In the case of organizational referents, there is ample evidence indicating that internal organizational referents can influence individual organizational behaviour: e.g., Kroll (2015b) on peer pressure regarding the use of decision support systems; Folz, Abdelrazek, and Chung (2009) on public managers' pressure to use of performance measures; Poister, and Streib (1999) on elected officials' pressure to use performance measures; Reynaert, and Steyvers (2010) on the pressure of a municipality's mayor on local councils to adopt rules, regulations and practices. External referents, on the other hand, are often responsible for the diffusion of normative rules on the conduct of professional behaviour which fosters normative isomorphism and behaviour (DiMaggio, and Powell 1983). Previous research indicated that external institutions such as consultancy firms (Berglund, and Werr 2000), management education institutions (Hackler, and Saxton 2007; Jarzabkowski et al. 2013) as well as higher level governments (Barrutia, and Echebarria 2019; Bryson, Edwards, and Van Slyke 2018; George et al. 2018) influence the diffusion of management tools within the public sector by acting as promotors of new ideas, models, or narratives. Therefore, we hypothesize that:

Hypotheses 2b. Perceived importance of strategic planning by organizational referents is positively related to perceived subjective norm which, in turn, positively impacts actual strategic plan use through its effect on intended strategic plan use.

Hypotheses 2c. Perceived importance of strategic planning by external referents is positively related to perceived subjective norm which, in turn, positively impacts actual strategic plan use through its effect on intended strategic plan use. 


\section{Perceived Behavioural Control: A Factor of Information, Training and Experience}

Perceived behavioural control refers to an individual's perception of the availability of skills and resources to perform a specific behaviour (Stevens et al. 2005). TPB argues that an individual's anticipated impediments towards performing a target behaviour effectively are negatively related to an individual's intention to perform a specific behaviour (Ajzen 1991): 'individuals will avoid activities believed to exceed their coping capabilities, but will undertake and perform those which they judge themselves to be capable of' (Armenakis, Harris, and Mossholder 1993, 686). Given that strategic planning in public organizations is considered to be a technical and rather complex process laden with jargon (Boyne et al. 2004; Bryson, Crosby, and Bryson 2009), the adoption of strategic planning processes requires specific skills (Bryson, Edwards, and Van Slyke 2018). These technical requirements could be at odds with the principle that in many countries political leadership of local governments is often trusted to laymen (Kleven et al. 2000). Although lay, often part-time, politicians can strengthen participatory democracy at a local level and help build a stronger local identity (Buchanan 2002; Kleven et al. 2000), their lack of experience with and knowledge of management tools can result in feelings of uncertainty and/or resistance (Fernandez, and Rainey 2006) which, in turn, could hinder the use of managerial tools. Therefore, we hypothesize that:

Hypothesis 3a. Perceived behavioural control is positively related to actual strategic plan use through its impact on intended strategic plan use.

Given that perceived behavioural control is argued to function as a motivational mechanism fostering strategic plan use, it is important to gain insights into the predictors of an individual's perceived behavioural control regarding strategic plan use. Based on prior research, we selected three relevant predictors: information about the strategic 
planning process, training related to strategic planning and experience with strategic planning. First, given that strategic planning processes are rather complex (Bryson, Berry, and Yang 2010), providing the involved politicians with accurate information about the planning process and development steps of the organization's strategic plan can clarify how a strategic plan can be used, where what kind of information can be found and how that information is formatted (Fernandez, and Rainey 2006; Wright, Paroutis, and Blettner 2013). Proving information about the organization's strategic planning process can act as an organizational intervention which increases politicians' domain-specific self-efficacy (Wanberg and Banas 2000, 134). Hence, we hypothesize:

Hypothesis 3b. Planning process information is positively related to perceived behavioural control which, in turn, positively impacts actual strategic plan use through its effect on intended strategic plan use.

Next to information, experience and training have also been proven to be positively related to the adoption of new practices within public sector settings (Demircioglu 2019; Torugsa and Arundel 2016; and Walker 2014). Specifically, training and experience are expected to foster perceived behavioural control and as such help politicians to deal with the complexity of strategic planning processes (Bryson, Crosby, and Bryson 2009) by acting as a source of information on the subject, its requirements and consequences (Hackler, and Saxton 2007; Kroll, and Moynihan 2015). Schedler (2003), for instance, indicated that intensively training politicians improves their adoption of managerial reforms. Boyne et al. (2005) demonstrated that past experience positively influences the capacity for innovation adoption in Welsh local governments while research by Boyne et al. (2004), based on data from U.K. local authorities, suggests that 
prior experience with some form of planning processes is positively related to the adoption of rational planning. Therefore, we hypothesize that:

Hypothesis 3c. Training is positively related to perceived behavioural control which, in turn, positively impacts actual strategic plan use through its effect on intended strategic plan use.

Hypothesis 3d. Prior experience is positively related to perceived behavioural control which, in turn, positively impacts actual strategic plan use through its effect on intended strategic plan use.

Although TPB states that attitudes, subjective norms and perceived behavioural control do not directly impact behaviour but that their effects are mediated by an individual's behavioural intention, Ajzen (1991) argues that perceived behavioural control can also directly predict behaviour. Specifically, Ajzen $(1991,184)$ reasons that, 'holding intention constant, the effort expended to bring a course of behaviour to a successful conclusion is likely to increase with perceived behavioural control'. This means that 'being in control over a behaviour can make its performance more likely, even if we leave aside behavioural intentions' (Kroll 2015b, 203). Aligned with TPB and the discussed predictors of perceived behavioural control, we hypothesize that:

Hypotheses 4a. Planning process information is positively related to perceived behavioural control which, in turn, impacts actual strategic plan use.

Hypotheses $4 \mathbf{b}$, Training is positively related to perceived behavioural control which, in turn, impacts actual strategic plan use.

Hypotheses 4c. Prior experience is positively related to perceived behavioural control which, in turn, impacts actual strategic plan use. 


\section{Methods}

\section{Empirical Setting and Data Collection}

Data to test the hypotheses were collected from the council members of Flemish (i.e., the Dutch-speaking part of Belgium) Public Centres for Social Welfare (PCSW). PCSW are local authorities responsible for organizing social services within a municipality. A PCSW is governed by a PCSW-council consisting of 9 to 15 members (depending on the population size of the municipality). PCSW-council members are appointed by the city council for a term of six years but nominated for the position by a political party represented in the city council. The number of candidates a political party can nominate is related to the party's representation in the city council. In almost all cases the nominees are party members who ran for city council but were not elected. The term of six years coincides with the term in office of the city council. Since the start of policy cycle of 2013-2019, PSCW are mandated by the Flemish government (i.e., the highest authority within the Dutch-speaking part of Belgium) to develop an integrated policy and management cycle (George, Desmidt, and De Moyer 2016). The policy and management cycle has characteristics comparable to the (U.K.) Best Value regime (Boyne, Martin, and Walker 2004) and relies heavily on the creation of a strategic plan. Specifically, legislation indicates that every local authority needs to develop a strategic plan according to content and development process guidelines. These regulations stipulate that the local authorities' strategic plan needs to consist of a strategic and a financial document. The strategic document clarifies a PCSW's strategic aspirations and insights on how a PCSW intends to realize these aspirations by offering an integrated set of policy priorities, goals, action plans and actions. The financial document lists the financial implications of the policy priorities stipulated in the strategic document. The fact that local authorities now 
need to formulate a coherent strategic vision which is supported by a financial document is one of the major changes of this NPM-driven reform given that previously financial statements and strategic planning documents often remained decoupled and scattered over different policy domains (Bleyen, Lombaert, and Bouckaert 2015). The development of the PCSW's strategic plan is the responsibility of a planning team chaired by the PCSW's senior manager. The PCSW-council, in turn, is legally responsible for approving the strategic plan, for monitoring its implementation as well as for the approval of annual strategic plan adjustments.

The fact that the local council's strategic plan is subjected to content and development process guidelines has a positive impact on the internal validity of the study. First, the fact that the PCSW-council is legally responsible for the strategic plan and has to formally approve the strategic plan (and its annual adjustments) helps to assure that council members of a local authority consider the same strategic framework when questioned about strategic plan use. Second, the fact that the strategic plan content and development process guidelines are legally binding for all Flemish local authorities guarantees that council members from different local councils refer to a comparable strategic artefact when asked to reflect on their strategic plan use.

Data were collected, using electronic surveys, in two waves (i.e., 2016 and 2017) with a lag time of approximately 1 year to allow for a temporal separation between the measurement of intended strategic plan use and actual strategic plan use. A database, developed by the Flemish government, containing descriptive information on 2,925 PCSW-council members was used as a sampling frame. Given that this database did not contain the email-addresses of the politicians seating on the 308 Flemish PCSW-councils, municipal and political party websites were scanned to identify politician's email- 
addresses. In total, 2,550 email-addresses were retrieved (87\% of the sampling frame). 594 council members responded to the electronic invitation (or one of three reminders) which resulted in 588 usable respondents nested in 234 PCSW (i.e., usable response rate of $23 \%$ ). Approximately 1 year after the first wave, the respondents were included in the research design of an unrelated study to measure discretely their actual plan use. In total, 249 council-members of 153 PCSW completed the survey of both the first and second wave. To assess if there were any significant differences between the characteristics of the population, respondents from wave 1 and wave 2, we conducted a series of clustercorrected logistic regressions. The results (see Table 1) provide support for the external validity of the sample given that the differences between the various groups are minor.

\section{[Insert Table 1 about here]}

The results also indicate that panel attrition is not likely to have a significant impact on the results. The odds ratios reported in Table 1 indicate that there are some differences between the respondents from wave 1 and wave 2, but that these differences are only statistically significant at the $10 \%$ level. More specifically, respondents from the right-winged party NVA are more likely to stay in the panel as well as respondents from larger municipalities while respondents from municipalities with a higher degree of citizens with a guaranteed minimum income are more likely to drop out. Further evidence that the impact of panel attrition is probably limited is provided by the fact a SEM-model with only the respondents from wave 1 provides comparable results to a model tested with only the respondents from wave 2 (see Appendix A for details).

\section{Measures}

Subjects' attributes were directly measured following the methodology suggested by Ajzen (2006), and Francis et al. (2004). As TPB has not yet been used to examine strategic 
plan use, the study uses items from other studies which were slightly adapted to reflect the focus of the study. All items are measured using a seven-point Likert scale (ranging from strongly disagree [1] to strongly agree [7]). Appendix B provides an overview of the selected items and their factor loadings.

Intended strategic plan use $($ Cronbach's alpha $=.86)$, which measures to what extent politicians intend to use the organization's strategic plan as a reference point for decision-making, is measured using an adaptation of Kroll and Moynihan's (2015) threeitem scale to measure strategic goal use. The same items (Cronbach's alpha $=.71$ ) were used in the second wave of data collection, although slightly adapted, to measure respondents' strategic plan use in the past year.

Attitude towards strategic planning (Cronbach's alpha $=.76$ ) measures the perceived benefits of adopting a strategic planning process within the respondents' local authority using an adaptation of Wright, Christensen, and Isett's (2013) scale to measure respondents' belief in the inherent benefits of an organizational change process.

Perceived subjective norm (Cronbach's alpha $=.94$ ) refers to a respondent's perceived social pressure to use organizational strategic plans as a decision-making support tool and is measured using an adapted version of three items used by Oliveira, Jarzabkowski, and Lee (2014) to assess management tool adoption. The social pressure emanating from organizational referents (Cronbach's alpha $=.82)$ to use strategic plans is measured using a four-item scale based on items developed by Taylor, and Todd (1995b) and Kroll (2015b) to measure peer pressure regarding the use of decision support systems. Perceived pressure from external referents (Cronbach's alpha $=.69)$ is measured using a four-item scale based on research on the impact of institutional pressures on strategic tool use (Jarzabkowski et al. 2013). 
Perceived behavioural control (Cronbach's alpha $=.70)$ denotes respondents' perceptions of their ability to successfully use strategic plans in decision-making processes and is measured using a three-item scale based on Venkatesh and Bala's (2008) measure of IT adoption and use. An adapted and shortened version of this scale has previously been used to assess management tool adoption (e.g., Oliveira, Jarzabkowski, and Lee 2014; Taylor, and Todd 1995a). The design also includes items measuring three hypothesized antecedents of perceived behavioural control. Information regarding the organization's strategic planning cycle (Cronbach's alpha $=.81$ ) is measured using an adapted version of the four-item scale on the quality of change-related information developed by Wright, Christensen, and Isett (2013). Both training (Cronbach's alpha = $.79)$ and experience in strategic planning (Cronbach's alpha $=.88)$ are measured using a three-item scale based on Kroll, and Moynihan's (2015) and Oliveira, Jarzabkowski, and Lee's (2014) scales used to measure received training in and experience with the use of performance information or management tools.

\section{Common Method Variance}

Common method variance due to the use of common source data, is deemed one of the most damaging sources of measurement error for surveys (Podsakoff, MacKenzie, and Podsakoff 2012). This observation leads to the juxtaposition that although self-reports are often theoretically the most relevant measurement method when studying individual-level attitudes and behaviour because individual perceptions are "critical determinants of individual behavior in organizations, mediating the relationship between objective characteristics of the work environment and individual responses' (Wright, Moynihan, and Pandey 2012, 209), such a design can inflate or deflate relationships between variables. To mitigate the potential negative effects of using common source data, we 
introduced temporal, psychological and proximal separations between predictor and criterion variables (Podsakoff, MacKenzie, and Podsakoff 2012). Temporal separation was established by measuring the predictor variables and the main criterion variable in two separate data collection waves. Psychological separation was introduced in both waves by imbedding the variables of interest in a broader survey. These additional variables functioned as buffer items to create physical distance between same-construct measures (i.e., proximal separation). In addition, we only used (adaptations of) previously published measures and followed the advice of Podsakoff, Mackenzie, and Podsakoff (2012) regarding survey development: we avoided complex, abstract, and doublebarrelled questions, eliminated ambiguous or unfamiliar terms and labelled all response options rather than just the end points respondents. A cover letter stating the importance of the research goals and guaranteeing anonymity was used to motivate the respondents to provide accurate responses.

\section{Data Analysis and Results}

Hypotheses are tested using SEM. Since the developed conceptual model contains latent variables and the respondents are nested in a higher-order group (i.e., PCSW), lavaan.survey (an R-package) (Oberski, Nov. 2015, version 1.1.3) was used to analyse the data. Lavaan.survey offers the advantage that latent variable models can be constructed while correcting for the nested survey design (Oberski 2014). Missing values were imputed into IBM SPSS Statistics 23 using EM missing value imputation (Little MCAR test Chi-square $=138.117, \mathrm{df}=143, \mathrm{p}=0.600$ ).

\section{Univariate and Bivariate Analysis}

Table 2 presents the univariate and bivariate statistics for the study's measures. 
[Insert Table 2 about here]

To provide more insights on the robustness of the identified relationships, Appendix C reports the results of a correlation analysis between (a) the variables from the developed theoretical model, (b) control variables rooted in the demographic characteristics of respondents, (c) control variables related to the political career of the respondents, and (d) control variables related to the organizational setting in which respondents are embedded. In addition, Appendix $\mathrm{C}$ also contains the results of two generalized linear regressions whereby intended plan use and actual plan use, respectively, act as the dependent variable and the control variables as the independent variables. Given that the impact of the control variables is, predominantly, non-significant, the results provide evidence for the robustness of the developed model.

\section{Multivariate Analysis}

The analysis of the latent variable model consists of two steps (Anderson, and Gerbing 1988). The first step assesses the fit of the measurement model to the data using a confirmatory factor analysis while in the second step the relationships between the constructs are estimated by means of a structural model. Both the measurement and structural model are analysed using pseudo-maximum likelihood estimation with bootstrapping $(5,000$ bootstrapped covariance matrices $)$ to determine the significance of the indirect effects (Preacher, and Hayes 2008). To facilitate interpretation, the nonstandardized parameter estimates of the estimated relationships are reported because this allows to retain a measure's original measurement unit.

\section{The Measurement Model.}

The fit indices indicate that the model captures the pattern of relationships found in the data as it meets the required thresholds (between brackets) advised by Hair, Black, and 
Babin (2010): the normed chi-square $=1.30(<5), \chi^{2} 331=431.38(\mathrm{p}<0.001)($ Lomax, and Schumacker 2004) with TLI $=0.96(\geq 0.92)$, CFI $=0.97(\geq 0.92)$, RMSEA $=0.04(<0.07$ with CFI $\geq 0.92)$ and $\mathrm{SRMR}=0.048(<0.08$ with $\mathrm{CFI} \geq 0.92)$. The constructs' Cronbach's alphas range from 0.69 to 0.94 , the loading of each factor is significantly different from zero and nontrivial (absolute standardized loadings $>0.60$ ), and all item factor loadings are significant while the average variance extracted and the construct reliability of each construct exceeds 0.50 and 0.60 respectively (see Appendix B for more details) (Hair, Black, and Babin 2010).

The Structural Model.

A structural model tested the significance and strength of each of the hypothesized effects. The developed model has a good fit: the normed chi-square $=1.30(<5), \chi^{2} 351=457.07$, $\mathrm{p}<0.001, \mathrm{TLI}=0.96(\geq 0.92), \mathrm{CFI}=0.97(\geq 0.92), \mathrm{RMSEA}=0.035(<0.07$ with $\mathrm{CFI} \geq$ 0.92), $\mathrm{SRMR}=0.056(<0.08$ with $\mathrm{CFI} \geq 0.92)$. Figure 2 reports the unstandardized effect sizes and significance of the relationships in the developed model.

[Insert Figure 2 about here]

The structural model explains $35 \%$ of the variance of intended strategic plan use and $28 \%$ of the variance of actual strategic plan use. Table 3 displays the unstandardized estimates and confidence intervals of the conducted mediation tests including both the direct and indirect effects.

\section{[Insert Table 3 about here]}

The results reported in Table 3 partly support the theory of reasoned action: a positive attitude towards strategic planning is positively related to a politician's intended strategic plan use which, in turn, positively impacts actual strategic plan use (Acceptance of H1) while there is no significant mediation between subjective norm, intended strategic 
plan use and actual strategic plan use (Rejection of $\mathrm{H} 2 \mathrm{a}$ ). The results also indicate that the formulated serial mediations regarding how specific referents impact actual strategic plan use are not significant (rejection of $\mathrm{H} 2 \mathrm{~b}$ and $\mathrm{H} 2 \mathrm{c}$ ). The findings suggest that a politician's perceptions of the importance that external and organizational referents attribute to strategic plan use, is positively related to a politician's perceived pressure to use a strategic plan which, in turn, positively impacts his or her intention to use a strategic plan (mediation significant at.10) but that this intention is not significantly related to actual strategic plan use. Furthermore, aligned with the propositions of TPB, the results indicate that including perceived behavioural control increases the predictive value of the model (Acceptance of $\mathrm{H} 3 \mathrm{a}$ ). The tested model also provides insights into the determinants of perceived behavioural control: the significant serial mediations indicate that planning process information $(\mathrm{H} 3 \mathrm{~b})$, training $(\mathrm{H} 3 \mathrm{c})$, and prior experience $(\mathrm{H} 3 \mathrm{~d})$ impact actual strategic plan use through their effect on perceived behavioural control and intended strategic plan use. Next to an indirect effect, perceived behavioural control has, as expected, a direct effect on actual strategic plan use whereby perceived behavioural control also mediates the relationship between planning process information ( $\mathrm{H} 4 \mathrm{a})$, training $(\mathrm{H} 4 \mathrm{~b})$, and prior experience $(\mathrm{H} 4 \mathrm{c})$, on the one hand, and actual strategic plan use on the other.

\section{Discussion}

Despite the fact that many supervising governments use legislation or regulation to mandate the adoption of NPM-inspired management tools in public organizations, little is known about the effectiveness of such "authority decisions" (Boyne et al. 2005) let alone if such "dictated process innovations" actually lead to the adoption of new 
managerial behaviours. This lack of knowledge is especially troublesome in the case of politicians serving on governing boards because although in many NPM-inspired reforms politicians are viewed as key strategic decision-makers whom are expected to use management tools (Walker, Jung, and Boyne 2013), politicians are also expected to display a certain amount of reluctance towards managerial innovations (Vabo 2000). To gain insights on politicians' adoption of management tools propelled by NPM-inspired reforms as well as on the underlying motivational mechanisms, this study examines strategic plan use by Flemish local councillors subjected to Flemish legislation directing the use of strategic planning processes.

The study findings indicate that, in contrast to what is often assumed (Vabo 2000), local politicians do not oppose against the adoption of strategic planning processes and the underlying managerial rationality but are, on average, modest to enthusiast adopters of this management approach (actual strategic plan use: mean $=5.05$, standard deviation $=1.23$ ). Flemish local politicians indicate that they, on average, consult their local authorities' strategic plan when engaging in strategic decision-making processes. The relatively high level of variance in actual plan use, however, indicates that mandating the use NPM-inspired management tools does not always result in the intended behavioural changes.

The relatively high variation in strategic plan use by politicians underlines the importance of gaining insights into the underlying motivational mechanisms fostering the adoption of management tools. The study results indicate that the variance in strategic plan use by politicians can be, in part, explained by politicians' attitude towards strategic planning, their perceived behavioural control, and to a lesser extent, pressure felt to adopt strategic planning. First, although it is often proposed that the logic of management is 
perpendicular to the logic of politics (Buylen, and Christiaens 2014; Hansen, and Ejersbo 2002; Liguori, Sicilia, and Steccolini 2012; Ter Bogt 2004), the results show that politicians are relatively supportive of the organization's strategic plan and believe that the adoption of such a rational planning instrument contributes to organizational performance (attitude: mean $=5.41$, standard deviation $=.96$ ). Second, the relatively strong direct and indirect effect of perceived behavioural control on intended and actual plan use is particularly noteworthy. These results confirm prior assertions that knowledge about strategic planning (Hendrick 2003) as well as strategic planning competencies and skills are facilitators of the adoption of strategic planning processes (Bryson, Edwards, and Van Slyke 2018; Kwon, Berry, and Jang 2014). However, despite the fact that the study results confirm that knowledge and competencies are key drivers of innovation adoption (De Vries, Bekkers, and Tummers 2016), the results also indicate that a large proportion of the participating politicians are doubtful about their knowledge with regard to their organization's strategic planning processes as well as their abilities to correctly interpret their organization's strategic plan (perceived behavioural control: mean $=4.76$, standard deviation $=1.19)$. These reservations could be rooted in the fact that there is a large variation amongst local politicians with respect to experience with strategic planning processes $($ mean $=3.98$, standard deviation $=1.71)$ as well as the degree of formal training on the subject $($ mean $=4.35$, standard deviation $=1.48)$. The relatively high level of variance in politicians' perceived behavioural control regarding effective strategic plan use not only constitutes a barrier to the adoption of strategic planning tools by politicians (Vabo 2000) but also points to a potential conflict between the democratic foundations of many local governments and the increasing level of managerialism within these organisations. To guarantee democracy and balanced decision-making many local 
governments are governed by a representative council of lay, part-time, politicians. These lay politicians now need to function in an environment characterized by managerial professionalization which expects them to be able to adopt technically complex managerial processes like strategic planning (Boyne, Law, and Walker 2004). The results, however, indicate that many local politicians struggle with the increasing technicality of management processes and are often not properly trained or informed to take up this role effectively. This lack of knowledge, in turn, could hinder local politicians ability to meet the requirements of internal control (Walker, Jung, and Boyne 2013).

Third, in contrast to the specifications of TPB, subjective norm is not significantly related to actual plan use. Although the total effect of perceived pressure exerted by internal and external referents marginally impacts intended strategic plan use through subjective norm (significance level $=.1$ ), the relationship with actual strategic plan use is not significant. These findings are at odds with the literature indicating that normative pressures arising from professional standards (Korac, Saliterer, and Walker 2017), vertical pressures emanating from higher government levels (Walker 2006) as well as support for innovation from municipal political leaders (e.g., the mayor) (Reynaert, and Steyvers 2010) and a supportive group culture foster innovation adoption (Barrutia, and Echebarria 2019; Ter Bogt 2004). A potential explanation for these divergent results could be that prior research predominantly used data collected at the organizational level (e.g., Walker 2006) or from managers (e.g., Oliveira, Jarzabkowski, and Lee 2014; Kroll $2015 \mathrm{~b}$ ) to assess the adoption of rational planning practices and tools. Politicians could be less susceptible to external and internal pressures to use such tools given their specific position within and relationship with the organization in comparison to managers (Pollitt 2006). Moreover, the fact that the vast majority of the respondents are lay, part-time, 
politicians could imply a lower degree of interaction with or exposure to specific organizational and external referents which, in turn, could provide an explanation for the limited effects of social norms.

The provided insights into the motivational mechanisms underlying strategic plan use by politicians also have practical implications. The study results indicate that mandating the use of management tools and instruments does not always produce the intended behavioural changes. However, the results indicate that politicians' attitudes towards strategic planning and their perceived behavioural control are positively related to strategic plan use. Hence, before starting a strategic planning process, it could be relevant to assess politicians' attitudes towards strategic planning as well as their strategic planning proficiency. When the assessed level of proficiency to use a strategic plan proofs to be insufficient, interventions aimed at closing the proficiency gap by providing information and training to politicians and share experiences on how to work with a strategic plan are recommendable. Increasing the level of information about the organisation's strategic planning process as well as strategy implementation could be useful to counter reservations regarding the benefits of strategic planning.

\section{Limitations and avenues for further research}

Notwithstanding the relevance of the study's findings at least three limitations need to be discussed. First, although consistent with reported results from other behavioural domains (De Leeuw et al. 2015), the fact that the structural model only explains $35 \%$ of the variance of intended strategic plan use and $28 \%$ of actual strategic plan use indicates that other variables are at play. Hence, more research is needed to uncover the additional motivational mechanisms and variables impacting strategic plan use. A viable option 
could be to assess the impact of variables related to strategic plan characteristics and strategic planning processes. Even in settings where strategic planning documents are subjected to content and development process guidelines, the depth and comprehensiveness of these documents may vary. Another potential research avenue is to investigate if (and which aspects of) strategic planning processes foster strategic plan use. This study did not account for potential differences in strategic planning processes and process involvement. Prior research, for example, suggests that, on average, councillors are only to a limited extent involved in strategic planning processes (George, and Desmidt 2018). In addition, more research is needed which provides insights into the discrepancy between actual and intended plan use. The results indicate that (1) intended plan use is higher than actual plan use and, (2) TPB is better suited to explain the variance in intended than actual plan use. Does the explanation lie in the fact there is a discrepancy between politicians' actual self-regulation skills and their perceived ones (De Leeuw et al. 2005) or do others factors matter? Could it be that politicians abandon strategic planning when they perceive that a managerial logic hinders their political logic the moment they are confronted with pressures emanating from stakeholders and/or constituents? Or, do characteristics of the strategy implementation process (e.g., implementation success, the provision of performance information or interaction and support with the organization's management team) influence politicians' motivation for actual strategic plan use? Weiss $(2017,1399)$, for example, argued that counciladministration interactions are critical for the implementation of management instruments and that 'the relation between elected politicians and administrative staff is highly relevant $[\ldots]$ to understand why and how these instruments are or are not implemented'. In addition, research by Kwon, Berry, and Jang (2013) indicated that internal capacity 
factors (e.g., risk-taking of administrative leaders) have a positive impact on the adoption of strategic management and the creation of a NPM-receptive organisational culture. Consequently, more knowledge is needed about how process design features and social mechanisms impact intended strategic plan use and the transition from intended to actual behaviour. Comparative, longitudinal case studies could help to shed light on this black box (Bryson, Edwards, and Van Slyke 2018).

Second, the data for this study was collected in a specific setting. Although NPMinspired reforms and related managerial tools are often presented as universally applicable, many authors find this assumption problematic. For instance Hajnal (2005) argues that the social, cultural and political differences between countries as well as regions may impact NPM-receptivity, while Verschuere and Barbieri $(2009,353)$ state that 'the NPM ideal-type will be modified by the existing national cultures and customs concerning innovation and reform in the administrative apparatus'.. Verschuere and Barbieri (2009), for example, also argue that Flanders has a regional culture which does not foster the adoption of managerial innovations because stability, certainty, predictability, risk-avoidance and status quo are, in general, preferred. Hence, more research is needed to assess the external validity of the study results. In addition, data for this study was collected half-way through the first policy and management cycle. More research is needed to verify if results are time point specific and to determine how experiences of adopting multiple sequential policy and management cycles will impact strategic plan use preferences. Furthermore, PCSW-councils are populated by appointed party-affiliated politicians. Given that ideology and political fragmentation of a board has been proven to impact how strategic plans are perceived by politicians serving on boards (Desmidt, Meyfroodt, and George 2019; Meyfroodt, Desmidt, and Goeminne 2019), 
future research should focus on analyzing if and how political characteristics at the individual level (e.g., appointed vs. elected politicians, party-affiliated or not) and group level (e.g., ideological differences and fragmentation within a council) impact the adoption of strategic planning.

Third, given the type of behaviour under investigation, reliance on self-reports is probably the only feasible measurement method. However, this entails that, despite the variety of incorporated counter measures, the presence of social desirability and common method bias can never be entirely excluded. Future research could complement survey research by, for example, analysing transcripts of council meetings to assess the extent to which the organization's strategic plan is referred to.

\section{Conclusion}

Although higher tier governments often mandate local authorities to adopt strategic planning processes to strengthen decision-quality and foster effective strategy implementation, knowledge about the impact of such authority decisions on the behaviour of an important group of strategic actors, namely politicians, is limited. The present study addresses this shortcoming by using the TPB to assess the motivational mechanisms prompting strategic plan use by politicians. The findings indicate that politicians are, on average, in favour of strategic planning and use the strategic plan of their local authority as a frame of reference during decision-making processes. Strategic plan use by politicians, in turn, is impacted by perceived behavioural control and the perceived benefits associated with the adoption of strategic planning processes. Strikingly, however, a large proportion of the politicians reported to be doubtful about their capabilities to correctly interpret their local authorities' strategic plan. The results call for more research 
on how the increasing managerialism within local authorities impacts politicians ability to carry out their democratic responsibility for organizational outcomes (Walker, Jung, and Boyne 2013). 


\section{References}

Ajzen, I. 2006. Constructing a theory of planned behavior questionnaire. Amherst, MA. Ajzen, I., and M. Fishbein. 1980. Understanding attitudes and predicting social behaviour. Prentice-Hall, Engelwood Cliffs, NJ.

Ajzen, I. 1991. "The theory of planned behavior." Organizational behavior and human decision processes 50(2): 179-211. Doi:10.1016/0749-5978(91)90020-T.

Amason, A.C. 1996. "Distinguishing the effects of functional and dysfunctional conflict on strategic decision making: Resolving a paradox for top management teams." Academy of management journal 39 (1): 123-148. Doi:10.5465/256633.

Anderson, J.C., and D.W. Gerbing. 1988. "Structural equation modeling in practice: A review and recommended two-step approach." Psychological bulletin 103 (3): 411-423.

Andrews, R., M. Beynon, and E. Genc. 2017. "Strategy implementation style and public service effectiveness, efficiency, and equity.” Administrative Sciences 7 (1): 4. Doi:10.3390/admsci7010004.

Armbruster, H., A. Bikfalvi, S. Kinkel, and G. Lay. 2008. “Organizational Innovation: The Challenge of Measuring Non-Technical Innovation in Large-Scale Surveys.” Technovation 28 (10): 644-657. Doi:10.1016/j.technovation.2008.03.003.

Armenakis, A.A., S.G. Harris, and K.W. Mossholder. 1993. "Creating readiness for organizational change." Human relations 46 (6): 681-703. Doi:10.1177/001872679304600601. 
Askim, J. 2009. “The demand side of performance measurement: Explaining councillors' utilization of performance information in policymaking." International Public Management Journal 12(1): 24-47. Doi:10.1080/10967490802649395.

Bandura, A. 1977. "Self-efficacy: toward a unifying theory of behavioral change." Psychological review 84 (2): 191-215. Doi:10.1037/0033-295X.84.2.191.

Barrutia, J.M., and C. Echebarria. 2019. "Drivers of Exploitative and Explorative Innovation in a Collaborative Public-sector Context." Public Management Review 21 (3): 446-472. Doi:10.1080/14719037.2018.1500630.

Berglund, J., and A. Werr. 2000. "The invincible character of management consulting rhetoric: How one blends incommensurates while keeping them apart." Organization 7 (4): 633-55. Doi:10.1177/135050840074008.

Berry, F.S. 1994. "Innovation in public management: The adoption of strategic planning." Public administration review 54 (4): 322-330. Doi:10.2307/977379.

Bleyen, P., S. Lombaert, and G. Bouckaert. 2015. "Measurement, incorporation and use of performance information in the budget: A methodological survey approach to map performance budgeting practices in local government." Society and Economy in Central and Eastern Europe 37 (3): 331-355. Doi:10.1556/204.2015.37.3.2.

Boyne, G., S. Martin, R. Walker. 2004. "Explicit reforms, implicit theories and public service improvement." Public Management Review 6 (2): 189-210. Doi:10.1080/1471903042000189092.

Boyne, G.A. 2001. "Planning, performance and public services." Public Administration 79 (1): 73-88. Doi:10.1111/1467-9299.00246. 
Boyne, G.A., and R.M. Walker. 2010. "Strategic management and public service performance: The way ahead.” Public administration review 70: s185-s192. Doi:10.1111/j.1540-6210.2010.02271.x.

Boyne, G.A., J.S. Gould-Williams, J. Law, and R.M. Walker. 2004. "Problems of rational planning in public organizations an empirical assessment of the conventional wisdom." Administration \& $\quad$ Society $36 \quad$ (3): $\quad 328-50$. Doi:10.1177/0095399704265294.

Boyne, G.A., J.S. Gould-Williams, J. Law, and R.M. Walker. 2005. "Explaining the adoption of innovation: An empirical analysis of public management reform." Environment and Planning C: Government and Policy 23 (3): 419-435. Doi:10.1068/c40m

Bryson, J.M. 2010. "The future of public and nonprofit strategic planning in the united states." Public Administration Review 70(s1): 255-267. Doi:10.1111/j.15406210.2010.02285.x.

Bryson, J.M., B.C. Crosby, and J.K. Bryson. 2009. "Understanding strategic planning and the formulation and implementation of strategic plans as a way of knowing: The contributions of actor-network theory." International Public Management Journal 12(2): 172-207. Doi:10.1080/10967490902873473.

Bryson, J.M., F.S. Berry, and K. Yang. 2010. "The state of public strategic management research: A selective literature review and set of future directions." The American Review of Public Administration 40(5): 495-521. Doi:10.1177/0275074010370361 
Bryson, J.M., L.H. Edwards, and D.M. Van Slyke. 2018. "Getting strategic about strategic planning research.” Public Management Review 20(3): 317-339. Doi:10.1080/14719037.2017.1285111.

Buchanan, A. 2002. Political legitimacy and democracy. Ethics 112 (4): 689-719.

Bush, P.D. 1987. "The theory of institutional change." Journal of Economic issues 21 (3): 1075-1116. Doi:10.1080/00213624.1987.11504697.

Buylen, B., and J. Christiaens. 2014. "Why are some Flemish Municipal Party Group Leaders more Familiar with NPM Principles than others? Assessing the Influence of Individual Factors.” Lex localis-Journal of Local Self-Government 12 (1): 79103. Doi:10.4335/12.1.79-103(2014).

De Leeuw, A., P. Valois, I. Ajzen, and P. Schmidt. 2015. "Using the theory of planned behavior to identify key beliefs underlying pro-environmental behavior in highschool students: Implications for educational interventions." Journal of Environmental Psychology 42: 128-138. Doi:10.1016/j.jenvp.2015.03.005.

De Vries, H., V. Bekkers, and L. Tummers. 2016. "Innovation in the public sector: A systematic review and future research agenda." Public administration 94 (1): 146166. Doi:10.1111/padm.12209.

Demircioglu M.A. 2019. "The effects of organizational and demographic context for innovation implementation in public organizations" Public Management Review Doi:10.1080/14719037.2019.1668467.

Desmidt, S., K. Meyfroodt, and B. George. 2019. "Shared strategic cognition in Flemish city councils: the relevance of political and demographic group characteristics." $\begin{array}{lllll}\text { Public } & \text { Management } & \text { (7): } & \text { 945-967. } & \text { DOI }\end{array}$ 10.1080/14719037.2018.1538423. 
Diefenbach, T. 2009. "New public management in public sector organizations: the dark sides of managerialistic ‘enlightenment'.” Public administration 87 (4): 892-909. Doi:10.1111/j.1467-9299.2009.01766.x.

DiMaggio, P., and W.W. Powell. 1983. "The iron cage revisited: Collective rationality and institutional isomorphism in organizational fields." American sociological review 48 (2): 147-160. Doi:10.2307/2095101.

Elbanna, S., R. Andrews, and R. Pollanen. 2016. "Strategic planning and implementation success in public service organizations: Evidence from canada." Public Management Review 18(7): 1017-1042. Doi:10.1080/14719037.2015.1051576.

Fernandez, S., and H.G. Rainey. 2006. "Managing successful organizational change in the public sector." Public Administration Review 66(2): 168-176.

Fishbein, M., and I. Ajzen. 1975. Belief, attitude, intention and behavior: An introduction to theory and research.

Fishbein, M., and I. Ajzen. 2011. Predicting and changing behavior: The reasoned action approach. Psychology Press.

Flemish Agency for local and Provincial Governance, retrieved from https://lokaalbestuur.vlaanderen.be/ .

Folz, D.H., R. Abdelrazek, and Y. Chung. 2009. “The adoption, use, and impacts of performance measures in medium-size cities: Progress toward performance management." Public Performance \& Management Review 33 (1): 63-87. Doi:10.2753/PMR1530-9576330103.

Francis, J., M.P. Eccles, M. Johnston, A. Walker, J. Grimshaw, R. Foy, E.F.S. Kaner, L. Smith, and D. Bonetti. 2004. Constructing questionnaires based on the theory of 
planned behaviour: A manual for health services researchers. Centre for Health Services Research, University of Newcastle upon Tyne.

George, B, S. Desmidt, and J. De Moyer. 2016. "Strategic decision quality in flemish municipalities." Public Money \& Management 36 (5): 317-324. Doi:10.1080/09540962.2016.1194073.

George, B. 2017. "Does strategic planning 'work'in public organizations? Insights from Flemish municipalities." Public Money \& Management 37(7): 527-530. Doi:10.1080/09540962.2017.1372116.

George, B., and S. Desmidt. 2018. "Strategic-decision quality in public organizations: An information processing perspective.” Administration \& Society 50 (1): 131-156. Doi:10.1177/0095399716647153.

George, B., S. Desmidt, E. Cools, and A. Prinzie. 2018. "Cognitive styles, user acceptance and commitment to strategic plans in public organizations." Public Management Review 20(3): 340-359. Doi:10.1080/14719037.2017.1285112.

George, B., S. Desmidt, P.A. Nielsen, and M. Baekgaard. 2017. "Rational planning and politicians' preferences for spending and reform: Replication and extension of a survey experiment." Public Management Review 19 (9): 1251-1271. Doi:10.1080/14719037.2016.1210905.

Grimmelikhuijsen, S., S. Jilke, A.L. Olsen, and L. Tummers. 2017. "Behavioral public administration: Combining insights from public administration and psychology.” Public Administration Review 77 (1): 45-56. Doi:10.1111/puar.12609.

Grissom, J.A. 2009. "The determinants of conflict on governing boards in public organizations: The case of California school boards." Journal of Public 
Administration Research and Theory, 20 (3): 601-627. doi:10.1093/jopart/mup043.

Hackler, D., and G.D. Saxton. 2007. "The strategic use of information technology by nonprofit organizations: Increasing capacity and untapped potential.” Public Administration Review 67 (3): 474-487. Doi:10.1111/j.1540-6210.2007.00730.x.

Hair, J.F., W.C. Black, and B. Babin. 2010. Multivariate data analysis (7). New Jersey: Prentice Hall.

Hansen, K. 2001. "Local councillors: between local 'government'and local 'governance'." Public administration 79 (1): 105-123. Doi:10.1111/14679299.00248.

Hansen, K.M., and N. Ejersbo. 2002. "The relationship between politicians and administrators-a logic of disharmony." Public Administration 80 (4): 733-750. Doi:10.1111/1467-9299.00326.

Hajnal, G. 2005 “The spirit of management reforms” Public Management Review 7 (4): 495-513. Doi:10.1080/14719030500362314.

Hendrick, R. 2003. "Strategic planning environment, process, and performance in public agencies: A comparative study of departments in Milwaukee.” Journal of Public Administration Research and Theory 13 (4): 491-519. Doi:10.1093/jpart/mug031.

Huse, M. 2005. “Accountability and creating accountability: A framework for exploring behavioural perspectives of corporate governance." British journal of management 16: S65-S79. Doi:10.1111/j.1467-8551.2005.00448.x.

Jacobsen, D.I. 2006. "The relationship between politics and administration: The importance of contingency factors, formal structure, demography, and time." Governance 19(2): 303-323. Doi:10.1111/j.1468-0491.2006.00316.x. 
Jarzabkowski, P., M. Giulietti, B. Oliveira, and N. Amoo. 2013. "We don't need no education — or do we? Management education and alumni adoption of strategy tools." Journal of Management Inquiry $22 \quad$ (1): 4-24. Doi:10.1177/1056492612460588.

Kellermanns, F.W., J. Walter, C. Lechner, and S.W. Floyd. 2005. "The lack of consensus about strategic consensus: Advancing theory and research." Journal of Management 31 (5): 719-737. Doi:10.1177/0149206305279114.

Kleven, T., T.S. Floris, M. Granberg, S. Montin, O. Rieper, and I. Valo. 2000. "Renewal of local government in Scandinavia: Effects for local politicians." Local Government Studies 26 (2): 93-116. Doi:10.1080/03003930008433991.

Korac, S., I. Saliterer, and R.M. Walker. 2017. “Analysing the environmental antecedents of innovation adoption among politicians and public managers." Public Management Review 19 (4): 566-587. Doi:10.1080/14719037.2016.1200119.

Kroll, A. 2015a. "Drivers of performance information use: Systematic literature review and directions for future research." Public Performance \& Management Review 38 (3): 459-486. Doi:10.1080/15309576.2015.1006469.

Kroll, A. 2015b. "Explaining the use of performance information by public managers: A planned-behavior approach.” The American Review of Public Administration 45 (2): 201-215. Doi:10.1177/0275074013486180.

Kroll, A. and D.P. Moynihan. 2015. "Does training matter? Evidence from performance management reforms." Public Administration Review 75(3): 411-420. Doi:10.1111/puar.12331.

Kwon, M., F.S. Berry, and H.S. Jang. 2013. "A theoretical framework on the determinants of strategic cities: Empirical results from Florida city governments." The 
American Review of Public Administration 43 (4): 438-459. Doi:10.1177/0275074012445308.

Kwon M., F.S. Berry, H.S. Jang. 2014. To Use or Not to Use Strategic Planning: Factors City Leaders Consider to Make This Choice. In: Joyce P., J.M. Bryson, M. Holzer (eds) Developments in Strategic and Public Management. IIAS Series: Governance and Public Management (International Institute of Administrative Sciences (IIAS) - Improving Administrative Sciences Worldwide). Palgrave Macmillan, London

Lee, D., M. McGuire, J.H. Kim. 2017. “Collaboration, strategic plans, and government performance: the case of efforts to reduce homelessness." Public Management Review 20 (3): 360-376. Doi:10.1080/14719037.2017.1285113.

Liguori, M., M. Sicilia, and I. Steccolini. 2009. "Politicians versus managers: roles and interactions in accounting cycles." International Journal of Public Sector Management 22 (4): 310-323. Doi:10.1108/09513550910961592.

Liguori, M., M. Sicilia, and I. Steccolini. 2012. “Some like it non-financial... Politicians' and managers' views on the importance of performance information." Public Management Review 14 (7): 903-922. Doi:10.1080/14719037.2011.650054.

Lomax, R.G. and R.E. Schumacker. 2004. A beginner's guide to structural equation modeling (2). Mahwah, NJ: Lawrence Erlbaum Associates.

Long, E. and A.L. Franklin. 2004. "The paradox of implementing the government performance and results act: top-down direction for bottom-up implementation.” Public Administration Review 64(3): 309-319. Doi:10.1111/j.15406210.2004.00375.x. 
Mason, R.O., and I.I. Mitroff. 1981. Challenging strategic planning assumptions: Theory, cases, and techniques. John Wiley \& Sons Inc.

Meier, K.J., and L.J. O’Toole Jr. 2006. Bureaucracy in a Democratic State: A Governance Perspective. Baltimore: Johns Hopkins University Press.

Meyfroodt, K., S. Desmidt, and S. Goeminne. 2019. "Do Politicians See Eye to Eye? The Relationship between Political Group Characteristics, Perceived Strategic Plan Quality, and Strategic Consensus in Local Governing Majorities.” Public Administration Review 1-11. doi:10.1111/puar.13058

Mintzberg, H., D. Raisinghani, and A. Theoret .1976. "The structure of 'unstructured' decision processes. Administrative science quarterly 21 (2): 246-275.

Moynihan, D.P., S.K. Pandey, and B.E. Wright. 2012. "Prosocial values and performance management theory: Linking perceived social impact and performance information use.“ Governance 25 (3): 463-483. Doi:10.1111/j.14680491.2012.01583.x.

Nielsen, P.A., and M. Baekgaard. 2015. "Performance information, blame avoidance, and politicians' attitudes to spending and reform: Evidence from an experiment." Journal of Public Administration Research and Theory 25(2): 545-569. Doi:10.1093/jopart/mut051.

Oberski, D.L. 2014. "lavaan.survey: An R package for complex survey analysis of structural equation models.” Journal of Statistical Software 57 (1): 1-27.

Oliveira, B., P. Jarzabkowski, and N. Lee. 2014. “Adoption of management practices: Explaining individual motivations toward strategy tools adoption.” In Academy of Management Proceedings, Briarcliff Manor, NY 10510: Academy of Management. 2014 (1): 12254. 
Pandey, S.K. and J.L. Garnett. 2006. "Exploring public sector communication performance: Testing a model and drawing implications." Public Administration Review 66 (1): 37-51. Doi:10.1111/j.1540-6210.2006.00554.x.

Podsakoff, P.M., S.B. MacKenzie, and N.P. Podsakoff. 2012. "Sources of method bias in social science research and recommendations on how to control it." Annual review of psychology 63: 539-69. Doi:10.1146/annurev-psych-120710-100452.

Poister, T.H. 2010. "The future of strategic planning in the public sector: Linking strategic management and performance." Public Administration Review 70(s1): 246-254. Doi:10.1111/j.1540-6210.2010.02284.x.

Poister, T.H., and G. Streib. 1999. "Performance measurement in municipal government: Assessing the state of the practice." Public administration review 59 (4): 325-335.

Poister, T.H., O.Q. Pasha, and L.H. Edwards. 2013. "Does performance management lead to better outcomes? Evidence from the us public transit industry." Public Administration Review 73(4): 625-636. Doi:10.1111/puar.2013.73.issue-4.

Pollitt, C. 2006. "Performance information for democracy: The missing link?." Evaluation 12 (1): 38-55. doi:10.1177/1356389006064191.

Pollitt, C., and G. Bouckaert. 2011. Continuity and change in public policy and management. Edward Elgar Publishing.

Preacher, K.J., and A.F. Hayes. 2008. "Asymptotic and resampling strategies for assessing and comparing indirect effects in multiple mediator models.” Behavior Research Methods 40 (3): 879-891. Doi:10.3758/BRM.40.3.879.

Reynaert, H., and K. Steyvers. 2010. De kerktorenpolitiek voorbij? Lokale politiek in Vlaanderen. Vanden Broele 
Ryan, R.M., and E.L. Deci. 2000a. "Intrinsic and extrinsic motivations: Classic definitions and new directions." Contemporary educational psychology 25(1): 5467. Doi:10.1006/ceps.1999.1020.

Ryan, R.M., and E.L. Deci. 2000b. "Self-determination theory and the facilitation of intrinsic motivation, social development, and well-being." American psychologist 55(1): 68 .

Saliterer, I., and S. Korac. 2014. "The discretionary use of performance information by different local government actors-analysing and comparing the predictive power of three factor sets." International Review of Administrative Sciences 80 (3): 637658. Doi:10.1177/0020852313518170

Schedler, K. 2003. “ ‘ ... and politics?' Public management developments in the light of two rationalities." Public Management Review 5 (4): 533-550. Doi:10.1080/1471903032000178572.

Spee, A.P., and P. Jarzabkowski. 2009. "Strategy tools as boundary objects." Strategic Organization 7 (2): 223-232. Doi:10.1177/1476127009102674.

Spee, A.P., and P. Jarzabkowski. 2011. "Strategic planning as communicative process." Organization Studies 32 (9): 1217-1245. Doi:10.1177/0170840611411387.

Stanec, A.D.S. 2009. "The theory of planned behavior: Predicting teachers' intentions and behavior during fitness testing." Journal of Teaching in Physical Education 28 (3): 255-271. Doi:10.1123/jtpe.28.3.255.

Stevens, J.M., H.K. Steensma, D.A. Harrison, and P.L. Cochran. 2005. "Symbolic or substantive document? The influence of ethics codes on financial executives' decisions." Strategic Management Journal $26 \quad$ (2): 181-195. Doi:10.1002/smj.440. 
Svara, J.H. 1985. "Dichotomy and duality: Reconceptualizing the relationship between policy and administration in council-manager cities." Public administration review 45 (1): 221-232. Doi:10.2307/3110151.

Svara, J.H. 1999. "Complementarity of politics and administration as a legitimate alternative to the dichotomy model." Administration \& society 30 (6): 676-705. Doi:10.1177/00953999922019049.

Svara, J.H. 2001. "The myth of the dichotomy: Complementarity of politics and administration in the past and future of public administration." Public administration review 61 (2): 176-183. Doi:10.1111/0033-3352.00020.

Taylor, S. and P.A. Todd. 1995a. “Assessing it usage: The role of prior experience.” MIS quarterly 19 (4): 561-70. Doi:10.2307/249633.

Taylor, S. and P.A. Todd. 1995b. "Understanding information technology usage: A test of competing models." Information systems research 6 (2): 144-176. Doi:10.1287/isre.6.2.144.

Teodoro, M.P. 2014. "When professionals lead: Executive management, normative isomorphism, and policy implementation." Journal of Public Administration Research and Theory 24 (4): 983-1004. Doi:10.1093/jopart/muu039.

Ter Bogt, H.J. 2004. "Politicians in Search of Performance Information?-Survey Research on Dutch Aldermen's Use of Performance Information.” Financial Accountability \& Management 20 (3): 221-252. Doi:10.1111/j.02674424.2004.00387.x

Torugsa, N., and A. Arundel. 2016. "Complexity of Innovation in the Public Sector: A Workgroup-level Analysis of Related Factors and Outcomes." Public Management Review 18 (3): 392-416. doi:10.1080/14719037.2014.984626. 
Vaara, E., V. Sorsa, and P. Palli. 2010. "On the force potential of strategy texts: a critical discourse analysis of a strategic plan and its power effects in a city organization." Organization 17(6): 685-702. Doi:10.1177/1350508410367326.

Vabo, S.I. 2000. "New organisational Solutions in Norwegian local councils: leaving a puzzling role for local politicians?.” Scandinavian Political Studies 23 (4): 343372. Doi:10.1111/1467-9477.00041.

Van de Walle, S. 2018. "Explaining Citizen Satisfaction and Dissatisfaction with Public Services. " In The Palgrave Handbook of Public Administration and Management in Europe, edited by E. Ongaro and S. Van Thiel, 227-241. London, UK: Palgrave Macmillan.

Van Dooren, W., and C. Hoffmann. 2018. Performance Management in Europe: An Idea Whose Time Has Come and Gone? in Ongaro, E., and S. van Thiel (eds.), The Palgrave Handbook of Public Administration and Management in Europe. London: Palgrave 207-224.

Venkatesh, V., and H. Bala. 2008. "Technology acceptance model 3 and a research agenda on interventions." Decision sciences 39 (2): 273-315. Doi:10.1111/j.15405915.2008.00192.x.

Verhoest, K., B. Verschuere, and G. Bouckaert. 2007. "Pressure, Legitimacy, and Innovative Behavior by Public Organizations.” Governance 20 (3): 469-497. doi:10.1111/gove.2007.20.issue-3.

Verschuere, B., and D. Barbieri. 2009. "Investigating the 'NPMness' of agencies in Italy and Flanders" Public Management Review 11(3): 345-373, Doi:10.1080/14719030902798271. 
Walker, R.M. 2006. Innovation type and diffusion: An empirical analysis of local government. Public administration, 84 (2): 311-335. Doi:10.1111/j.14679299.2006.00004.x.

Walker, R.M. 2008. “An Empirical Evaluation of Innovation Types and Organizational and Environmental Characteristics: Towards a Configuration Framework." Journal of Public Administration Research and Theory 18 (4): 591-615. doi:10.1093/jopart/mum026.

Walker, R.M. 2014. "Internal and External Antecedents of Process Innovation: A Review and Extension." Public Management Review 16 (1): 21-44. doi:10.1080/14719037.2013.771698.

Walker, R.M., and G.A. Brewer. 2008. "An organizational echelon analysis of the determinants of red tape in public organizations." Public Administration Review 68 (6): 1112-1127. Doi:10.1111/j.1540-6210.2008.00959.x.

Walker, R.M., C.N Avellaneda, and F.S. Berry. 2011. "Exploring the diffusion of innovation among high and low innovative localities: A test of the Berry and Berry model." Public Management Review 13 (1): 95-125. Doi:10.1080/14719037.2010.501616.

Walker, R.M., C.S. Jung, and G.A. Boyne. 2013. "Marching to different drummers? The performance effects of alignment between political and managerial perceptions of performance management." Public Administration Review 73(6): 833-844. Doi:10.1111/puar.12131.

Walker, R.M., G.A. Boyne, and G.A. Brewer. 2010. "Public management and performance: Research directions." Cambridge University Press. 
Wanberg, C.R., and J.T. Banas. 2000. "Predictors and outcomes of openness to changes in a reorganizing workplace.” Journal of applied psychology 85 (1): 132-142.

Weiss, J. 2017. "Trust as a key for strategic management? The relevance of counciladministration relations for NPM-related reforms in German local governments." $\begin{array}{llll}\text { Public } & \text { Management } & \text { Review } & 19\end{array}$ Doi:10.1080/14719037.2016.1266023.

Wolf, C., and S.W. Floyd. 2017. "Strategic planning research toward a theory-driven agenda." Journal of Management $43 \quad$ (6): 1754-1788. Doi: $10.1177 / 0149206313478185$.

Wright, B.E., D.P. Moynihan, and S.K. Pandey. 2012. "Pulling the levers: Transformational leadership, public service motivation, and mission valence." Public Administration Review 72 (2): 206-215. Doi:10.1111/j.15406210.2011.02496.x.

Wright, B.E., R.K. Christensen, and K.R. Isett. 2013. "Motivated to adapt? The role of public service motivation as employees face organizational change." Public Administration Review 73 (5): 738-747. Doi:10.1111/puar.12078.

Wright, R.P., S.E. Paroutis, and D.P. Blettner. 2013. "How useful are the strategic tools we teach in business schools?" Journal of Management Studies 50 (1): 92-125. Doi:10.1111/j.1467-6486.2012.01082.x. 
Figure 1. Conceptual Model

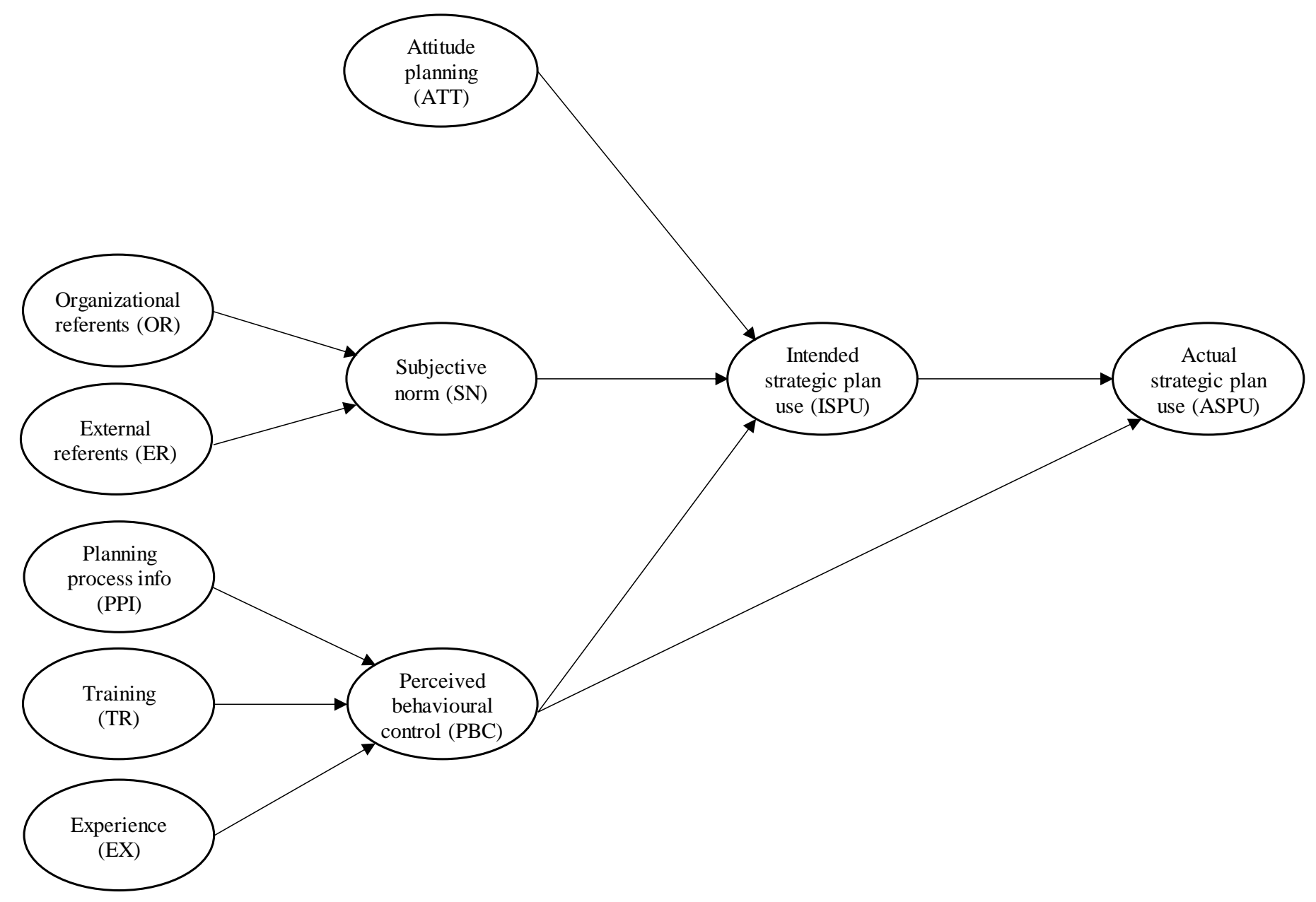


Figure 2. Overview of the study results

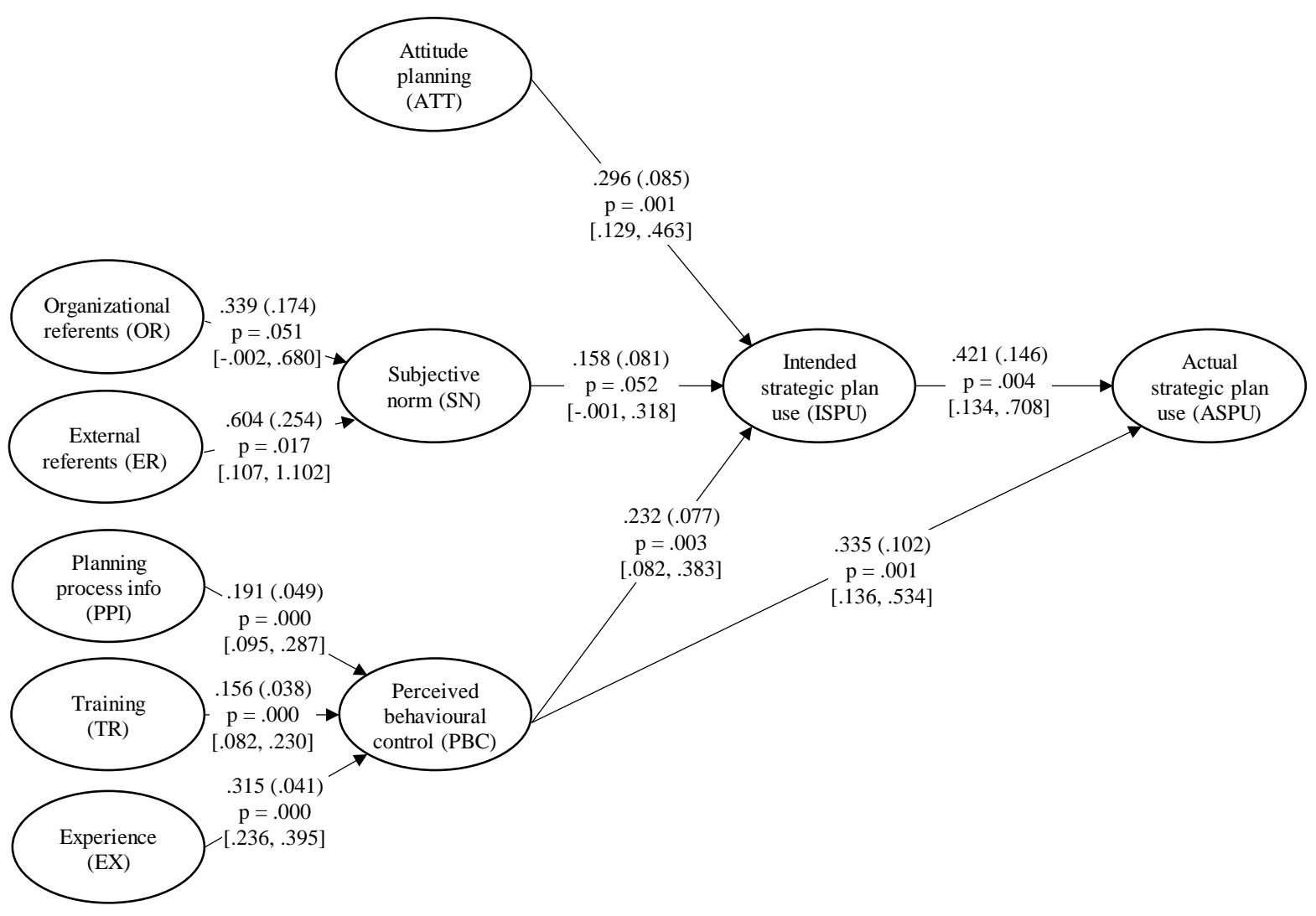

Note

For each relation the unstandardized point estimate, the standard error (between parenthesis), the significance and the 95\% bias-corrected bootstrap confidence interval are listed (between brackets). Standard errors are clustered at the municipal level. 
Table 1. Validity of the sample

\begin{tabular}{|c|c|c|c|c|c|c|c|c|c|c|}
\hline & \multicolumn{3}{|c|}{$\begin{array}{l}\text { Comparison respondents } \\
\text { wave } 1 \text { with population }\end{array}$} & \multicolumn{3}{|c|}{$\begin{array}{l}\text { Comparison respondents } \\
\text { wave } 2 \text { with population }\end{array}$} & \multicolumn{4}{|c|}{$\begin{array}{l}\text { Comparison respondents wave } \\
2 \text { with wave } 1 \\
\end{array}$} \\
\hline & B & s.e. & $\begin{array}{c}\text { p- } \\
\text { value }\end{array}$ & B & s.e. & $\begin{array}{c}\mathrm{p}- \\
\text { value }\end{array}$ & B & s.e. & $\begin{array}{c}\text { p- } \\
\text { value }\end{array}$ & $\operatorname{Exp}(\mathrm{B})$ \\
\hline \multicolumn{11}{|l|}{ Respondent characteristics } \\
\hline Gender (Male is reference category) & .135 & .096 & .163 & .003 & .130 & .981 & -.221 & .177 & .212 & .081 \\
\hline \multicolumn{11}{|l|}{ Party membership ('Other' is reference category) } \\
\hline NVA & .210 & .168 & .212 & $.436^{+}$ & .223 & .052 & $.486^{+}$ & .283 & .088 & 1.625 \\
\hline $\mathrm{CD} \& \mathrm{~V}$ & .117 & .144 & .416 & .084 & .182 & .645 & -.104 & .265 & .695 & .901 \\
\hline Open VLD & $.429^{*}$ & .203 & .035 & $.459^{+}$ & .251 & .068 & .085 & .347 & .807 & 1.089 \\
\hline SPA & .163 & .214 & .447 & .120 & .269 & .657 & -.081 & .392 & .837 & .922 \\
\hline Groen &.$-516^{+}$ & .268 & .055 & -.300 & .349 & .391 & .322 & .511 & .529 & 1.379 \\
\hline Age & - & - & - & - & - & - & -.003 & .010 & .785 & .997 \\
\hline \multicolumn{11}{|l|}{ Level of education (Master degree or $\mathrm{PhD}$ is reference group) } \\
\hline Primary or secondary education & - & - & - & - & - & - & .306 & .259 & .239 & 1.357 \\
\hline Bachelor degree & - & - & - & - & - & - & 319 & .233 & .173 & 1.376 \\
\hline Political tenure (Years in office) & - & - & - & - & - & - & .008 & .019 & 669 & 1.008 \\
\hline \multicolumn{11}{|l|}{ Municipal characteristics } \\
\hline Median income citizens & .005 & .018 & .781 & -.038 & .046 & .414 & -.001 & -.100 & .977 & .999 \\
\hline Guaranteed minimum income citizens (per 1000 inhabitants) & -.048 & .038 & .206 & -.017 & .017 & .335 & $-.040^{+}$ & -.086 & .089 & .961 \\
\hline Inhabitants & -.002 & .001 & .163 & .000 & .001 & .875 & $.002^{+}$ & .001 & .078 & 1.002 \\
\hline Intercept & $2.785 * *$ & 1.053 & .009 & $3.389 * *$ & 1.271 & .008 & .002 & 1.415 & .999 & - \\
\hline Test of model effects: Wald $\chi^{2}$ & $2.125^{*}$ & - & .027 & 1.295 & - & .239 & .980 & - & .472 & \\
\hline N (Politicians) & & 2925 & & & 2925 & & & & 38 & \\
\hline $\mathrm{N}(\mathrm{PCSW})$ & & 305 & & & 305 & & & & 15 & \\
\hline
\end{tabular}

Note

Logistic regression. Standard errors are clustered at the municipal level. p-values ${ }^{+}{ }^{+} \mathrm{p}<0.10,{ }^{*} \mathrm{p}<0.05,{ }^{*} \mathrm{p}<0.01$ (two-tailed test). 
Table 2: Descriptive statistics for the research constructs $(N=249)$

\begin{tabular}{|c|c|c|c|c|c|c|c|c|c|c|c|c|c|c|}
\hline & \multirow{2}{*}{ Mean } & \multirow{2}{*}{ SD } & \multirow{2}{*}{ Min. } & \multirow{2}{*}{$\operatorname{Max}$} & \multicolumn{10}{|c|}{ Pearson correlations, Cronbach's alpha (in parentheses), and descriptives } \\
\hline & & & & & 1 & 2. & 3. & 4. & 5. & 6. & 7. & 8. & 9. & 10. \\
\hline 1. Actual strategic plan use & 5.05 & 1.23 & 1 & 7 & (.86) & & & & & & & & & \\
\hline 2. Intended strategic plan use & 5.43 & .87 & 1 & 7 & $.34 * *$ & (.71) & & & & & & & & \\
\hline 3. Attitude towards planning & 5.41 & .96 & 1 & 7 & $24 * *$ & $.55^{* *}$ & $(.76)$ & & & & & & & \\
\hline 4. Subjective norm & 5.13 & .92 & 2 & 7 & $.14^{*}$ & $.33^{* *}$ & $.46^{* *}$ & $(.94)$ & & & & & & \\
\hline 5. Perceived behavioural control & 4.76 & 1.19 & 1.67 & 7 & $.30^{* *}$ & $.31^{* *}$ & $.32 * *$ & $.20 * *$ & $(.82)$ & & & & & \\
\hline 6. Organizational referents & 5.30 & .86 & 2.33 & 7 & $.15^{*}$ & $.25 * *$ & $36 * *$ & $.40^{* *}$ & $.20 * *$ & (.69) & & & & \\
\hline 7. External referents & 4.94 & .74 & 3 & 6.5 & .01 & $.28 * *$ & $.30 * *$ & $.41^{* *}$ & $.25 * *$ & $.41^{* *}$ & $(.70)$ & & & \\
\hline 8. Planning process information & 4.98 & 1.11 & 1.33 & 7 & $26 * *$ & $.29 * *$ & $.31 * *$ & $.24 * *$ & $.76 * *$ & $.32 * *$ & $21 * *$ & $(.81)$ & & \\
\hline 9. Training & 4.35 & 1.48 & 1 & 7 & $.23 * *$ & $.20 * *$ & $.17 * *$ & $.14^{* *}$ & $.61^{* *}$ & .07 & $.17 * *$ & $.53 * *$ & (.79) & \\
\hline 10. Experience & 3.98 & 1.71 & 1 & 7 & $.19 * *$ & $.21 * *$ & $.26 * *$ & .11 & $.65^{* *}$ & .05 & $.20 * *$ & $.43^{* * *}$ & $.43^{* *}$ & $(.88)$ \\
\hline
\end{tabular}

Note

*Correlation is significant at the .05 level (2-tailed).

${ }^{* *}$ Correlation is significant at the 01 level (2-tailed). 
Table 3: Unstandardized estimates and confidence interval limits for the mediation tests

\begin{tabular}{|c|c|c|c|c|c|c|c|c|c|c|}
\hline & \multirow{2}{*}{ Path } & \multicolumn{3}{|c|}{ Direct effect } & \multicolumn{3}{|c|}{ Indirect effect } & \multicolumn{3}{|c|}{ Total effect } \\
\hline & & $b(S E)$ & $95 \% \mathrm{CI}$ & Sign. & $b(S E)$ & $95 \% \mathrm{CI}$ & Sign. & $b(S E)$ & $95 \% \mathrm{CI}$ & Sign. \\
\hline & $\mathrm{ER} \rightarrow \mathrm{SN} \rightarrow \mathrm{ISPU}$ & & & & $.096(.064)$ & {$[-.030, .221]$} & .135 & $.149(.082)$ & {$[-.011, .309]$} & .068 \\
\hline & $\mathrm{OR} \rightarrow \mathrm{SN} \rightarrow$ ISPU & & & & $.054(.039)$ & {$[-.024, .131]$} & .173 & $.149(.082)$ & {$[-.011, .309]$} & .068 \\
\hline & PPI $\rightarrow$ PBC $\rightarrow$ ISPU & & & & $.044(.016)$ & {$[.012, .076]$} & .007 & $.154(.049)$ & {$[.058, .249]$} & .002 \\
\hline & $\mathrm{TR} \rightarrow \mathrm{PBC} \rightarrow \mathrm{ISPU}$ & & & & $.036(.014)$ & {$[.008, .064]$} & .012 & $.154(.049)$ & {$[.058, .249]$} & .002 \\
\hline & $\mathrm{EX} \rightarrow \mathrm{PBC} \rightarrow \mathrm{ISPU}$ & & & & $.073(.025)$ & {$[.024, .122]$} & .003 & $.154(.049)$ & {$[.058, .249]$} & .002 \\
\hline & TOTAL EFFECT ON ISPU & & & & & & & $.599(.115)$ & {$[.374, .825]$} & .000 \\
\hline H1 & ATT $\rightarrow$ ISPU $\rightarrow$ ASPU & & & & $.125(.059)$ & {$[.009 .240]$} & .034 & $.125(.059)$ & [.009.240] & .034 \\
\hline $\mathrm{H} 2 \mathrm{a}$ & $\mathrm{SN} \rightarrow \mathrm{ISPU} \rightarrow \mathrm{ASPU}$ & & & & $.067(.045)$ & {$[-0.021, .155]$} & .138 & $.067(.045)$ & {$[-0.021, .155]$} & .138 \\
\hline $\mathrm{H} 2 \mathrm{~b}$ & $\mathrm{ER} \rightarrow \mathrm{SN} \rightarrow \mathrm{ISPU} \rightarrow \mathrm{ASPU}$ & & & & $.040(.032)$ & {$[-.022, .103]$} & .205 & $.063(.044)$ & {$[-.024, .150]$} & .156 \\
\hline $\mathrm{H} 2 \mathrm{c}$ & $\mathrm{OR} \rightarrow \mathrm{SN} \rightarrow \mathrm{ISPU} \rightarrow \mathrm{ASPU}$ & & & & $.023(.020)$ & {$[-.016, .062]$} & .256 & $.063(.044)$ & {$[-.024, .150]$} & .156 \\
\hline H3a & $\mathrm{PBC} \rightarrow \mathrm{ISPU} \rightarrow \mathrm{ASPU}$ & $.335(.102)$ & {$[.126, .534]$} & .001 & $.098(.038)$ & {$[.023, .172]$} & .010 & $.433(.101)$ & {$[.234, .631]$} & .000 \\
\hline $\mathrm{H} 3 \mathrm{~b}$ & $\mathrm{PPI} \rightarrow \mathrm{PBC} \rightarrow \mathrm{ISPU} \rightarrow \mathrm{ASPU}$ & & & & $.019(.008)$ & {$[.003, .034]$} & .019 & $.065(.024)$ & {$[.017, .112]$} & .008 \\
\hline $\mathrm{H} 3 \mathrm{c}$ & $\mathrm{TR} \rightarrow \mathrm{PBC} \rightarrow \mathrm{ISPU} \rightarrow \mathrm{ASPU}$ & & & & $.015(.006)$ & {$[.003, .028]$} & .019 & $.065(.024)$ & {$[.017, .112]$} & .008 \\
\hline H3d & $\mathrm{EX} \rightarrow \mathrm{PBC} \rightarrow \mathrm{ISPU} \rightarrow \mathrm{ASPU}$ & & & & $.031(.012)$ & {$[.007, .055]$} & .013 & $.065(.024)$ & {$[.017, .112]$} & .008 \\
\hline $\mathrm{H} 4 \mathrm{a}$ & $\mathrm{PPI} \rightarrow \mathrm{PBC} \rightarrow \mathrm{ASPU}$ & & & & $.064(.026)$ & {$[.013, .115]$} & .013 & $.222(.068)$ & {$[.088, .355]$} & .001 \\
\hline $\mathrm{H} 4 \mathrm{~b}$ & $\mathrm{TR} \rightarrow \mathrm{PBC} \rightarrow \mathrm{ASPU}$ & & & & $.052(.019)$ & {$[.015, .090]$} & .007 & $.222(.068)$ & {$[.088, .355]$} & .001 \\
\hline \multirow[t]{2}{*}{$\mathrm{H} 4 \mathrm{c}$} & $\mathrm{EX} \rightarrow \mathrm{PBC} \rightarrow \mathrm{ASPU}$ & & & & $.106(.033)$ & {$[.041, .170]$} & .001 & $.222(.068)$ & {$[.088, .355]$} & .001 \\
\hline & TOTAL EFFECT ON ASPU & & & & & & & $.474(.098)$ & {$[.281, .667]$} & .002 \\
\hline
\end{tabular}

Note

ASPU $=$ Actual strategic plan use, ISPU $=$ Intended strategic plan use, ATT $=$ Attitude towards planning, ER $=$ External referents, $\mathrm{SN}=\mathrm{Subjective} \mathrm{norm}, \mathrm{OR}$

$=$ Organizational referents, $\mathrm{PPI}=$ Planning process information, $\mathrm{PBC}=$ Perceived behavioural control, $\mathrm{TR}=\mathrm{Training}, \mathrm{EX}=$ Experience 